\title{
El endeudamiento corporativo: pautas prácticas para ponderar sus beneficios y amenazas ${ }^{1}$
}

Corporate Indebtedness: practical guidelines to ponder their benefits and threats

\author{
Javier Dusso \\ Facultad de Ciencias Económicas - \\ Universidad Nacional del Litoral, Argentina \\ E-mail: javdusso@hotmail.com
}

Palabras clave

- Deuda

- Estructura de capital

- Desempeño corporativo

- Ciclo económico

- Diagrama de decisión

\section{Resumen}

El endeudamiento de las empresas está expuesto a diversos riesgos. Por ello, el objetivo final del presente trabajo es poder brindar un conjunto de herramientas que actúen como marco referencial para ponderar diferentes modalidades de endeudamiento y contribuir así a que las empresas tomen las decisiones que mejor se adapten a sus necesidades y preferencias.

El artículo se inicia con un análisis de los principales aportes teóricos en la materia. Posteriormente, en base al relevamiento de diferentes variables económico financieras, se analiza la relación entre niveles de endeudamiento y desempeño corporativo, arribando así a la formulación de las conclusiones del trabajo.

\footnotetext{
Abstract

When a company borrows money, it is exposed to different kind of risks. Thus this work main objective is to provide a set of tools to ponder different modes of borrowing, allowing the company to choose the one that fits with its needs and preferences.
} 


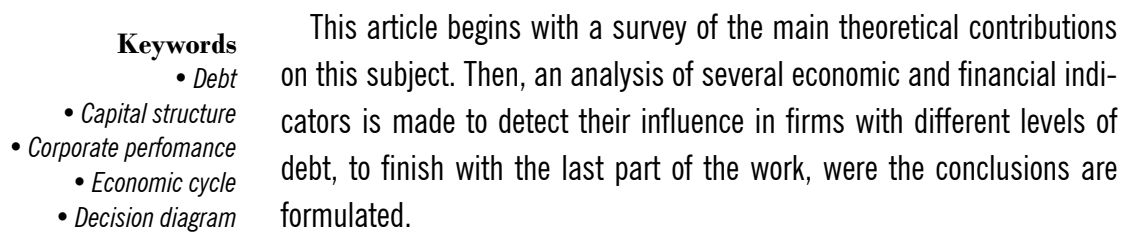

This article begins with a survey of the main theoretical contributions on this subject. Then, an analysis of several economic and financial indicators is made to detect their influence in firms with different levels of formulated.

\section{Introducción}

A efectos de una mejor comprensión del artículo, resulta necesario aclarar que a los fines del presente trabajo se entiende por deuda a la toma de fondos desde fuentes ajenas a la tesorería de la empresa, con el compromiso de restituirlos en una fecha futura.

Resulta importante entonces mencionar que la conceptualización precedente excluye al saldo impago por la adquisición de bienes o servicios que no se abonan en forma inmediata, sino en una fecha posterior convenida con los proveedores de tales bienes o los prestadores del servicio en cuestión. Esta exclusión no resulta caprichosa, ya que aunque los casos fuera de consideración también constituyen deuda en el sentido jurídico de la palabra, no se vinculan con la obtención de fondos y la consecuente obligación de devolverlos, sino más bien con cuestiones atinentes a la administración del capital trabajo, tema de suma importancia en la gestión de una compañía, pero que no forma parte del eje central de este artículo.

Asimismo, el título del presente trabajo podría inducir a creer que el endeudarse es una decisión sujeta a reglas claramente establecidas, las cuales asegurarían que se trate de un proceso armónico, tendiente a compatibilizar los objetivos de las empresas y organizaciones en general con la obligación de restituir los fondos tomados en préstamo.

Pues bien, más allá del título, la realidad indica (y así se expondrá durante el desarrollo del trabajo) que el endeudamiento obedece a múltiples motivaciones y está expuesto a diversos riesgos, no exis- tiendo manuales con recetas infalibles que prescriban la mejor forma de tomar dinero prestado.

Es decir, sin llegar a la pretensión de brindar tales recetas infalibles, pretensión que incluso puede ser inviable dada la dinámica propia de los procesos de endeudamiento, este artículo procura brindar un aporte concreto a la gestión del financiamiento corporativo, lo cual se abordó a partir de un trabajo estructurado de la siguiente manera:

\section{Objetivos}

\section{Generales}

- Diseñar un sistema de análisis de variables económicas y financieras, tendiente a determinar si la modalidad de endeudamiento financiero que la organización tiene previsto encarar es compatible con su normal desenvolvimiento en el mediano y largo plazo. - Lograr que dicho sistema actúe como un mecanismo de alerta temprana en caso de que se pretendan adoptar decisiones de endeudamiento financiero inadecuadas.

\section{Específicos}

- Presentar un marco conceptual en materia de financiamiento empresarial, sustentado en los principales aportes teóricos que al respecto existen y en las características jurídicas y operativas de los mercados financieros y de capitales argentinos.

- Detectar los patrones de endeudamiento adoptados por empresas que - en cuanto a sus niveles de actividad — se cuentan entre las más relevantes de Argentina. 